\title{
Pengembangan Perangkat Pembelajaran TIK Berbasis Macromedia Director di SMP Negeri 3 Woha
}

\author{
Nur Fitrianingsih \\ STKIP Taman Siswa Bims \\ nurfitrianingsih984@gmail.com
}

\begin{abstract}
ABSTRAK
Tujuan penelitian ini untuk menghasilkan suatu perangkat pembelajaran TIK berbasis macromedia director yang valid, praktis, dan efektif pada pada pokok bahasan perangkat lunak pengolah angka untuk siswa kelas VIII SMP Negeri 3 Woha. Metode yang digunakan dalam penelitian ini adalah penelitian Research and Development (R\&D) dengan menggunakan model Four-D yang dikembangkan oleh Thiagarajan yang terdiri dari tiga tahapan yaitu pendefinisian (define), perancangan (design), dan pengembangan (develop), dengan teknik pengumpulan data melalui observasi, wawancara, dan kuesioner. Pada tahapan pendefinisian, dilakukan analisis batasan materi pembelajaran yang akan divisualisasikan. Pada tahapan perancangan bertujuan untuk merancang prototype perangkat pembelajaran. Untuk tahapan pengembangan, produk awal media pembelajaran diuji kelayakannya dengan cara divalidasi oleh ahli media dan ahli materi, perbaikan dilakukan setelah adanya masukan dari para ahli. Ujicoba produk untuk menguji keefektifan dan kepraktisan. Media pembelajaran dilakukan pada kelas VIII-10 SMP Negeri 3 Woha yang terdiri dari 3 orang siswa untuk ujicoba perorangan, 10 orang siswa untuk ujicoba kelompok kecil dan 20 orang siswa untuk ujicoba lapangan, pada setiap akhir ujicoba dilakukan revisi sesuai hasil penilaian subjek coba. Teknik analisis yang digunakan adalah statistik deskriptif, dengan mengkategorikan setiap jawaban subjek coba.
\end{abstract}

Kata kunci: Macromedia Director, Pembelajaran TIK, Pengembangan Perangkat Pembelajaran.

\section{PENDAHULUAN}

Perkembangan ilmu pengetahuan dan teknologi (IPTEK) yang semakin pesat telah membawa implikasi perubahan dalam dunia pendidikan. Segala perubahan yang terjadi dalam kehidupan masyarakat membuat dunia pendidikan terus menyesuaikan diri, berubah sesuai dengan perkembangan zaman. Dunia pendidikan sangat terkait dengan siswa sebagai peserta didik yang merupakan subjek utama dalam pendidikan. Siswa harus dibekali dengan pengetahuan, keterampilan, dan sikap yang memungkinkannya untuk mandiri, sehingga dapat memberikan kontribusi yang bermanfaat bagi pembangunan bangsa dan negara.

Pendidikan adalah usaha sadar untuk menumbuhkembangkan potensi sumber daya manusia melalui kegiatan pembelajaran. Dalam proses pembelajaran akan terjadi interaksi antara siswa dan pendidik. Siswa adalah seseorang atau sekelompok orang sebagai pencari, penerima pelajaran yang dibutuhkannya, sedangkan pendidik adalah seseorang atau sekelompok orang yang berprofesi sebagai pengolah kegiatan pembelajaran dan seperangkat peranan lainnya yang memungkinkan berlangsungnya kegiatan pembelajaran yang efektif. Kegiatan pembelajaran melibatkan beberapa komponen, yaitu siswa, guru (pendidik), tujuan pembelajaran, materi pelajaran, model dan pendekatan serta metode pembelajaran, media dan evaluasi.

Suatu proses pembelajaran dapat berjalan efektif bila seluruh komponen yang berpengaruh dalam proses belajar mengajar (PBM) saling mendukung dalam rangka mencapai tujuan. Oleh karena itu, diperlukan usaha-usaha yang inovatif dan kreatif untuk meningkatkan kualitas pembelajaran. Sebab di samping untuk mencapai tujuan pembelajaran juga harus memperhatikan dan mempertimbangkan aspekaspek dan karakteristik pembelajaran.

Sebagai salah satu komponen dalam proses pembelajaran, guru memiliki posisi yang 
menentukan keberhasilan pembelajaran, karena guru merupakan ujung tombak yang secara langsung berhubungan dengan siswa sebagai objek dan subjek belajar. Oleh karena itu, berkualitas atau tidaknya proses pembelajaran sangat tergantung pada kemampuan dan perilaku guru dalam pengelolaan pembelajaran. Dengan kata lain, guru merupakan faktor penting yang dapat menentukan kualitas pembelajaran. Kualitas pembelajaran dapat dilihat dari dua sisi, yaitu sisi proses dan sisi hasil belajar.

Proses pembelajaran sering terjadi masalah yang dihadapi siswa maupun guru sendiri. Salah satu permasalahan yang dihadapi dunia pendidikan kita adalah rendahnya kualitas pembelajaran dalam hal ini proses dan hasil belajar yang dicapai siswa. Rendahnya kualitas hasil belajar ditandai oleh pencapaian prestasi belajar yang belum memenuhi standar kompetensi seperti tuntutan kurikulum. Dari segi hasil belajar yang dicapai siswa dapat dilihat pada masa akhir tahun ajaran sekolah yang ditunjukkan dengan rendahnya hasil nilai Ujian Akhir Nasional (UAN).

Di sisi yang sama pada dasawarsa terakhir, bidang informasi dan telekomunikasi mengalami revolusi. Teknologi tersebut telah mengubah cara hidup masyarakat dan berpengaruh terhadap beberapa aspek kehidupan. Mata pelajaran Teknologi Informasi dan Komunikasi dipersiapkan untuk mengantisipasi dampak perkembangan teknologi khususnya bidang informasi dan komunikasi dalam kehidupan kita sehari-hari. Mata pelajaran ini perlu dikenalkan, dipraktekkan dan dikuasi oleh siswa sedini mungkin agar siswa memiliki bekal untuk menyesuaikan penerapan teknologi informasi dan komunikasi.

Hasil pengamatan ke beberapa sekolah untuk tingkat SMP hampir semua sekolah sudah memiliki laboratorium komputer, sayangnya ini tidak didukung oleh sumber daya manusia (SDM) guru yang memadai. Lulusan Ilmu Komputer atau Teknik Informatika banyak, tapi mereka tidak memiliki akta mengajar. Akhirnya kebanyakan dari guru TIK yang ada merupakan guru mata pelajaran bidang lain yang beralih menjadi guru TIK. Diperlukan guru TIK yang memiliki kemampuan mengajar sekaligus kemampuan di bidang Komputer.

Berdasarkan pengamatan nampak bahwa yang diajarkan terfokus pada pengajaran komputer dengan perangkat lunak tertentu, sedangkan TIK sendiri menurut kurikulum 2004 bukanlah komputer. Visi mata pelajaran Teknologi Informasi dan Komunikasi menurut kurikulum TIK 2004 yaitu agar siswa dapat menggunakan perangkat Teknologi Informasi dan Komunikasi secara tepat dan optimal untuk mendapatkan dan memproses informasi dalam kegiatan belajar, bekerja, dan aktifitas lainnya sehingga siswa mampu berkreasi, mengembangkan sikap inisiatif, mengembangkan kemampuan eksplorasi mandiri, dan mudah beradaptasi dengan perkembangan yang baru. Berdasarkan visi kurikulum TIK adalah untuk menciptakan siswa yang mampu mengatur diri dalam belajarnya.

Pelajaran TIK diperlukan peralatan yaitu komputer. Dari hasil pengamatan, kebanyakan siswa mampu mengoperasikan komputer karena mereka telah belajar komputer sejak SD. Siswa lebih tertarik menerima pelajaran melalui praktek (simulasi melalui media) dibandingkan teori karena mereka terbiasa belajar visual dan audiotorial. Mengubah metode pembelajaran yang digunakan guru, yang tadinya menggunakan metode ceramah diganti dengan metode lain yang lebih mengaktifkan siswa (siswa yang mendominasi pembelajaran).

Kurikulum 2013/2014 terbaru saat ini terdapat banyak perubahan mata pelajaran mulai dari tingkat SD sampai tingkat SMA. Salah satunya adalah pada tingkat SMP dimana dulu kurikulum sebelumnya terdapat 12 mata pelajaran (mapel) disusutkan menjadi 10 mata pelajaran (mapel) saja. Salah satu mata pelajaran yang ditiadakan dalam kurikulum ini adalah pelajaran teknologi informasi dan komunikasi (TIK). Menurut Kemdikbud Bapak Muhammad Nuh, Mapel TIK di SMP akan ditiadakan. TIK akan menjadi media pembelajaran semua mata pelajaran sehingga komputer tidak diajarkan secara terpisah. Hal ini akan membawa perubahan yang saat besar dikalangan guru. 
Tidak dapat dipungkiri saat ini, selain murid masih banyak guru yang belum mampu menguasai TIK.

Adanya kurikulum 2013/2014 diharuskan semua guru khususnya pada tingkat SMP sudah dapat menguasai TIK, walaupun kurikulum ini masih dalam taraf sosialisasi dan akan yang dimulai awal tahun 2014 secara bertahap mulai dari kelas 1, 4, 7 dan 9. Dengan adannya kurikulum ini penulis tertarik membuat perangkat pembelajaran TIK yang bukan hanya dapat digunakan oleh siswa melainkan juga dapat digunakan guru sebagai multimedia dalam membantu guru untuk belajar menguasai TIK.

Berdasarkan latar belakang masalah yang dikemukakan diatas secara operasional masalah dalam artikel ini dirumuskan dalam bentuk pertanyaan yaitu: "Bagaimana proses dan hasil pengembangan perangkat pembelajaran TIK berbasis macromedia director pada pokok bahasan penggunaan perangkat lunak pengolah angka yang berkualitas baik (valid, praktis dan efektif) siswa kelas VIII SMP Negeri 3 Woha?" Sedangkan tujuannya adalah untuk menghasilkan suatu perangkat pembelajaran TIK berbasis macromedia director yang valid, praktis, dan efektif pada pada pokok bahasan perangkat lunak pengolah angka untuk siswa kelas VIII SMP Negeri 3 Woha.

Untuk menghasilkan perangkat pembelajaran yang baik, perlu ditempuh suatu prosedur tertentu, yakni mengacu pada model pengembangan sistem pembelajaran atau mengacu pada model pengembangan perangkat pembelajaran. Menurut Twelker (Mudhofir, 1990:33) bahwa yang dimaksud dengan pengembangan sistem pembelajaran adalah suatu cara yang sistematis dalam mengidentifikasi, mengembangkan dan mengevaluasi seperangkat materi dan strategi yang diarahkan untuk mencapai tujuan tertentu. Sedangkan menurut Butler (Alhadad, 2002: 22) menyatakan bahwa pengembangan sistem pembelajaran pada hakekatnya terdiri atas empat fase, yaitu: (1) menetapkan tujuan sistem, (2) mengembangkan desain tahap awal, (3) mengembangkan, mengetes dan merevisi sistem, serta (4) melaksanakan sistem yang teruji.
Perangkat pembelajaran adalah sekumpulan sumber belajar yang memungkinkan siswa dan guru melakukan kegiatan pembelajaran. Ibrahim (2002:3) menyatakan bahwa ibarat pasukan yang akan berperang memerlukan logistik, seorang guru yang akan "bertempur" di dalam kelas pun memerlukan sejumlah piranti/perangkat pembelajaran yang akan membantu dan memudahkan proses mengajar belajarnya dan memberikan pengalaman kepada siswa dalam rangka mencapai tujuan yang sudah ditentukan. Perumpamaan di atas memberikan gambaran tentang pentingnya perangkat pembelajaran bagi guru dalam mengelola pembelajaran. Sehubungan dengan hal tersebut Usman (2001: 24) menyatakan perangkat pembelajaran merupakan prasyarat bagi terjadinya interaksi belajar mengajar yang optimal. Jadi jelas bahwa perangkat pembelajaran akan mempengaruhi keberhasilan proses pembelajaran di kelas. Oleh sebab itu perangkat pembelajaran mutlak diperlukan oleh seorang guru dalam mengelola pembelajaran.

Macromedia Director MX 2004 atau lebih dikenal dengan nama Director MX 2004 adalah program canggih untuk membuat presentasi multimedia interaktif. Director MX 2004 juga banyak digunakan untuk membuat animasi, game, video tutorial interaktif dan berbagai aplikasi multimedia lainnya yang dapat didistribusikan melalui Compact Disc (CD), Digital Video Disc (DVD), dan Internet. Macromedia Director MX 2004 merupakan sebuah program untuk membantu anda dalam membuar animasi atau multimedia yang interaktif. Macromedia Director MX 2004 memiliki fasilitas pengaturan untuk membuat suatu animasi per frame dan animasi tiga dimensi (Hendi Hendratman, 2011).

\section{METODE PENELITIAN}

Model pengembangan yang digunakan dalam perangkat pembelajaran adalah menggunakan model four-D (Thiagarajan, Semmel dan Semmel,1974) dengan tahapan define, design, develop, dan disseminate atau diadaptasikan menjadi Model 4-P, yaitu Pendefinisian, 
Perencanaan, Pengembangan, dan Penyebaran (Ibrahim,2003).

Lokasi penelitian ini dilaksanakan di SMP Negeri 3 Woha Kabupaten Bima Propinsi Nusa Tenggara Barat Tahun ajaran 2016/2017 semester II, dengan objek uji coba dalam penelitian ini adalah perangkat pembelajaran TIK berbasis macromedia director pokok bahasan perangkat lunak pengolah angka, sedangkan subjek uji coba adalah siswa Kelas VIII.10 sebanyak 20 orang (laki-laki 10 orang, perempuan 10 orang).

Jenis data yang dikumpulkan berupa data kualitatif dan kuantitatif yang terdiri dari data primer dan data sekunder. Data kualitatif diperoleh melalui teknik pengumpulan data seperti wawancara, analisis dokumen, diskusi terfokus, atau observasi yang telah di tuangkan dalam catatan lapangan. Bentuk lain data kualitatif adalah gambar yang diperoleh melalui pemotretan atau video. Data kuantitatif merupakan data berbentuk angka-angka baik secara langsung dari hasil penelitian maupun hasil pengolahan data kualitatif menjadi data kuantitatif. Sedangkan data sekunder yang bersifat kualitatif dan kuantitatif diperoleh dari artikel, buku-buku, dan dokumen yang berhubungan dengan penelitian pengembangan media pembelajaran.

Tabel 1. Jenis data dan sumber data

\begin{tabular}{|c|c|c|c|}
\hline No & Jenis data & Sumber data & Ket \\
\hline 1 & $\begin{array}{l}\text { Penilaian } \\
\text { Media }\end{array}$ & Ahli media & $\begin{array}{c}1 \\
\text { Orang }\end{array}$ \\
\hline 2 & $\begin{array}{l}\text { Penilaian } \\
\text { Materi }\end{array}$ & Ahli materi & $\begin{array}{c}1 \\
\text { Orang }\end{array}$ \\
\hline 3 & $\begin{array}{l}\text { Uji coba } \\
\text { kelompok kecil }\end{array}$ & Siswa kelompok kecil & $\begin{array}{c}10 \\
\text { Orang }\end{array}$ \\
\hline 4 & $\begin{array}{l}\text { Uji coba } \\
\text { lapangan }\end{array}$ & $\begin{array}{l}\text { Siswa kelompok } \\
\text { diperluas }\end{array}$ & \multirow{7}{*}{$\begin{array}{c}20 \\
\text { Orang }\end{array}$} \\
\hline 5 & Aspek aplikasi & $\begin{array}{l}\text { Siswa kelompok } \\
\text { diperluas }\end{array}$ & \\
\hline 6 & $\begin{array}{l}\text { Aspek } \\
\text { tampilan }\end{array}$ & $\begin{array}{l}\text { Siswa kelompok } \\
\text { diperluas }\end{array}$ & \\
\hline 7 & Aspek isi & $\begin{array}{l}\text { Siswa kelompok } \\
\text { diperluas }\end{array}$ & \\
\hline 8 & Aspek materi & $\begin{array}{l}\text { Siswa kelompok } \\
\text { diperluas }\end{array}$ & \\
\hline 9 & Keefektifan & $\begin{array}{l}\text { Siswa kelompok } \\
\text { diperluas }\end{array}$ & \\
\hline 10 & Kepraktisan & $\begin{array}{l}\text { Siswa kelompok } \\
\text { diperluas }\end{array}$ & \\
\hline
\end{tabular}

\section{Instrumen Pengumpulan Data}

Instrumen penelitian yang digunakan untuk mengembangkan perangkat pembelajaran TIK berbasis Macromedia Director ini adalah sebagai berikut:

1) Wawancara, digunakan untuk melengkapi informasi yang diperoleh dari kuesioner yang diisi oleh penilai, dalam hal ini ahli media, dan ahli materi. Wawancara juga dimungkinkan dilakukan terhadap siswa dan guru mata pelajaran TIK atau kelompok siswa dan guru uji coba media pembelajaran, untuk melengkapi angket yang mereka isi serta memperoleh saran perbaikan dan atau kelayakan produk dari ahli, guru dan siswa yang terlibat selama proses penelitian pengembangan produk.

2) Observasi, digunakan langsung oleh peneliti untuk melihat bagaimana respon siswa terhadap media perangkat pembelajaran TIK berbasis Macromedia Director yang dikembangkan. Pedoman observasi aktifitas guru digunakan untuk menilai guru dalam menerapkan pengembangan perangkat pembelajaran yang dikembangkan. Pedoman observasi aktifitas siswa digunakan untuk mengamati aktifitas siswa selama kegiatan pembelajaran berlangsung. Observasi aktifitas guru dilakukan oleh siswa dengan cara mengisi lembar observasi setelah pembelajaran selesai. Sedangkan observasi siswa dilakukan secara langsung saat pembelajaran berlangsung oleh guru observer. Hal ini dilakukan untuk melihat keefektifan produk yang dikembangkan.

3) Dokumentasi, untuk memperoleh data sekunder berupa data-data SMP Negeri 1 Pallangga yang telah ada sebelumnya dilakukan oleh penelitian misalnya dokumen kurikulum/SKKD perangkat lunak pengolah angka.

4) Kuesioner, untuk menjaring data validasi dari ahli materi dan ahli media, kuesioner evaluasi siswa pada uji coba awal, uji coba kelompok kecil dan uji coba kelompok diperluas. Pada dasarnya kuesioner juga menjaring tanggapan pengguna mengenai media pembelajaran yang dikembangkan dengan melihat aspek aplikasi, 
tampilan, isi dan materi untuk melihat kevalidan produk. Disamping itu menjaring juga tanggapan pengguna mengenai keefektifan penggunaan media pembelajaran.

\section{Kisi-Kisi Instrumen}

Kisi-kisi ini dikembangkan dengan indikatorindikator yang disesuaikan dengan analisis kebutuhan di lapangan. Instrumen masingmasing terbagi untuk validasi ahli yang terdiri dari instrumen untuk ahli media (aplikasi dan tampilan) dan intrumen ahli materi (content/isi dan makna dalam penyampaian gambar, vidio, dan audio) serta instrumen yang digunakan oleh guru dan siswa dalam mengevaluasi produk yang berasal dari turunan instrumen dari ahli materi dan media.

\section{Teknik Analisis Data}

1) Analisis Data Kevalidan

Kategori validitas setiap aspek atau keseluruhan aspek yang dinilai diterapkan berdasarkan kriteria pengkategorian kualitas perangkat dan media yang diadaptasi dari pengkategorian menurut Saifuddin Azwar (2009:72) sebagai berikut

Tabel 2. Kategori Validitas

\begin{tabular}{cll}
\hline No & Interval & Kategori \\
\hline 1 & $3,5 \leq \mathrm{M}<4,0$ & Sangat valid \\
\hline 2 & $2,5 \leq \mathrm{M}<3,5$ & Valid \\
\hline 3 & $1,5 \leq \mathrm{M}<2,5$ & Cukup valid \\
\hline 4 & $1,0 \leq \mathrm{M}<1,5$ & Tidak valid \\
\hline
\end{tabular}

2) Analisis Data Respon Guru dan Siswa

Data yang diperoleh dari pemberian angket/kuesioner dianalisis dengan menentukan banyaknya siswa yang memberikan jawaban bernilai respon positif dan negatif untuk setiap kategori yang ditanyakan dalam angket. Setelah data respon siswa dan guru diperoleh maka selanjutnya dianalisis dengan data statistik deskriptif dengan skor rata-rata. Dari hasil persentase yang diperoleh kemudian dicocokkan dengan kriteria telah ditetapkan.

Kriteria yang ditetapkan untuk mengatakan bahwa para siswa memiliki respon positif terhadap media pembelajaran adalah lebih dari 50 persen dari mereka memberi respon positif terhadap minimal 70 persen jumlah aspek yang ditanyakan
(Nurdin, 2007). Respon siswa dan guru dianggap positif apabila memberikan tanggapan sangat setuju atau setuju begitupun sebaliknya respon siswa dianggap negatif apabila memberikan tanggapan kurang setuju atau tidak setuju.

Untuk menganalisis respon/tanggapan siswa terhadap aspek aplikasi, aspek tampilan, aspen content/isi, dan aspek materi jaringan komputer dari produk media pembelajaran diginakan kategorisasi yang dihitung berdasarkan kurva normal dengan kriteria sebagai berikut:

Tabel 3. Kategori respon siswa

\begin{tabular}{cll}
\hline No & Interval & Kategori \\
\hline 1 & $3,5 \leq M<4,0$ & Sangat setuju \\
\hline 2 & $2,5 \leq M<3,5$ & Setuju \\
\hline 3 & $1,5 \leq M<2,5$ & Kurang setuju \\
\hline 4 & $1,0 \leq M<1,5$ & Tidak setuju \\
\hline
\end{tabular}

3) Analisis Data Aktivitas Guru

Data tentang aktivitas guru dalam proses pembelajaran diperoleh dengan menggunakan statistik deskriptif dengan skor rata-rata dari pengamat. Dari hasil pengamatan observer ditentukan nilai kegiatan guru (KG) dalam mengelola pembelajaran menggunakan produk pengembangan perangkat pembelajaran TIK berbasis macromedia director. Selanjutnya nilai $K G$ ini dikonfirmasikan dengan interval penentuan kategori kemampuan guru dalam proses pembelajaran yang diadaptasi dari Saifuddin Azwar (2009) sebagai berikut:

Tabel 4. Kategori Aktifitas Guru

\begin{tabular}{|c|c|c|}
\hline No & Interval & Kategori \\
\hline 1 & $3,5 \leq K G \leq 4,0$ & Sangat baik \\
\hline 2 & $2,5 \leq K G<3,5$ & Baik \\
\hline 3 & $1,5 \leq K G<2,5$ & Cukup baik \\
\hline 4 & $1,0 \leq K G<1,5$ & Kurang baik \\
\hline
\end{tabular}

Data tentang aktifitas siswa dalam proses pembelajaran diperoleh dari hasil pengamatan pada tiap kali pertemuan uji coba produk media pembelajaran (uji coba awal, terbatas/kelompok kecil, diperluas) yang dianalisis menggunakan statistik deskriptif dengan skor rata-rata (M) pengamat. Selanjutnya nilai aktivitas siswa ini 
dikonfirmasikan dengan interval penentuan kategori aktivitas siswa dalam proses pembelajaran yang diadaptasi dari Saifuddin Azwar (2009) sebagai berikut:

\begin{tabular}{ccl}
\multicolumn{3}{c}{ Tabel 5. Kategori aktivitas siswa } \\
\hline No & Interval & \multicolumn{1}{c}{ Kategori } \\
\hline 1 & $3,5 \leq \mathrm{M} \leq 4,0$ & Sangat baik \\
\hline 2 & $2,5 \leq \mathrm{M}<3,5$ & Baik \\
\hline 3 & $1,5 \leq \mathrm{M}<2,5$ & Cukup baik \\
\hline 4 & $1,0 \leq \mathrm{M}<1,5$ & Kurang baik \\
\hline
\end{tabular}

4) Analisis Data Keefektifan

Keefektifan media pembelajaran yang sedang dikembangkan dapat ditentukan dengan memperhatikan data hasil analisis respon siswa dan guru, aktifitas guru, dan tes hasil belajar siswa. Suatu media dapat dikatakan efektif apabila respon siswa dan guru positif dalam artian minimal kategori setuju, dan untuk aktifitas guru minimal kategori baik, sedangkan untuk tes hasil belajar siswa dianalisis dengan menggunakan persentase skor yang benar dari seluruh butir soal yang diberikan.

Penentuan keefektifan media pembelajaran didasarkan pada kriteria nilai tertentu yaitu dengan membandingkan tingkat penguasaan siswa terhadap materi yang diberikan sebelum menggunakan media pembelajaran interaktif yaitu dengan dasar KKM (Kriteria Ketuntasan Minimal) yang telah ditentukan pada standar kompetensi menggunakan perangkat lunak pengolah angka. Apabila secara keseluruhan 80 persen atau lebih nilai yang diperoleh siswa setelah menggunakan media pembelajaran interaktif sama atau lebih tinggi dari KKM maka media tersebut layak dikategorikan efektif.

\section{HASIL DAN PEMBAHASAN}

Pada hasil penelitian yang meliputi empat hal, yaitu: pertama ketercapaian tujuan penelitian, Ketercapaian tujuan penelitian meliputi:

a) Kevalidan. Berdasarkan hasil penelitian mengenai uji kevalidan, dapat disimpulkan bahwa prototipe media perangkat pembelajaran tik berbasis macromedia director secara keseluruhan telah memenuhi kriteria kevalidan. Adapun paparan hasil penilaian validator dan uji coba produk sebagai berikut: berdasarkan analisis penilaian oleh dua validator, diperoleh bahwa pada penilaian media dan materi yang terdapat pada media pembelajaran tik berbasis macromedia director diperoleh hasil valid untuk setiap pernyataan yang diberikan, baik pada aspek aplikasi, aspek tampilan, aspek content/isi.

b) Kepraktisan. Secara teoritis, hasil penilaian ahli dan praktisi terhadap media perangkat pembelajaran TIK berbasis macromedia director menyatakan bahwa media perangkat layak di gunakan dalam pembelajaran. Sedangkan secara empirik, berdasarkan hasil pengamatan terhadap perangkat pembelajaran oleh dua observer menyatakan bahwa media perangkat pembelajaran TIK berbasis macromedia director terlaksana dengan baik pada saat uji coba. Berdasarkan hasil penilaian pengamat, maka perangkat pembelajaran telah memenuhi kriteria kepraktisan.

c) Keefektifan. Kriteria keefektifan perangkat pembelajaran yang meliputi: tes hasil belajar, kemampuan guru mengelola pembelajaran, aktivitas siswa, respons siswa dan respons guru. Kriteria yang harus dipenuhi sehingga suatu perangkat pembelajaran dikatakan efektif adalah 3 dari 5 kriteria tersebut harus terpenuhi, tetapi indikator 1 harus terpenuhi dan pada hasil penelitian ini semua indikator tersebut terpenuhi dan telah dilaksanakan pada uji coba lapangan.

Kedua: kendala-kendala yang ditemui. Kendala yang dihadapi dalam pengembangan media perangkat pembelajaran TIK berbasis macromedia director ini terkait masalah software bawaan dari macromedia director. Untuk menjalankan program ini dibutuhkan spesifikasi komputer minimum Pentium IV, RAM 128 MB dan LCD 14" sehingga siswa yang memiliki notebook kecil dengan spesifikasi yang kecil tidak dapat menjalankan media ini di notebooknya.

Ketiga: kelemahan-kelemahan penelitian. Adapun kelemahan-kelemahan dalam penelitian 
antara lain: Ujicoba lapangan hanya dilakukan pada satu kelas saja yaitu di Kelas VIII-10 SMP Negeri 1 Pallangga. Pada lembar aktivitas siswa, pengumpulan data dilakukan oleh satu observer, siswa yang dipilih untuk diamati aktivitasnya adalah hanya 20 orang siswa saja, jelas data yang diperoleh bersifat bias, karena tidak semua siswa teramati. Perangkat yang dikembangkan terbatas pada standar kompetensi penggunaan perangkat lunak pengolah angka saja

\section{KESIMPULAN}

1) Proses pengembangan TIK berbasis macromedia director di SMP melalui tahap pendefinisian (define) dan perancangan (design) menghasilkan draf awal perangkat TIK berbasis macromedia director. Kemudian tahap pengembangan (develop) yang berfokus pada aspek aplikasi, aspek tampilan, aspek content/isi dan aspek materi yang menghasilkan prototype perangkat pembelajaran TIK berbasis macromedia director yang valid, praktis, dan efektif.

2) Berdasarkan analisis deskriptif diperoleh bahwa perangkat pembelajaran TIK berbasis macromedia director praktis untuk mengajarkan pokok bahasan penggunaan perangkat lunak pengolah angka. Hal ini ditunjukkan syarat-syarat kepraktisan pembelajaran telah terpenuhi, yaitu: keterlaksanaan media perangkat dan ketuntasan belajar secara klasikal tercapai.

3) Produk perangkat pembelajaran yang dihasilkan efektif digunakan dalam pembelajaran yang sebenarnya. Hal ini dibuktikan dari beberapa indikator keefektifan berada pada kategori baik. (a) penilaian ahli media dengan kategori sangat baik, dan penilaian ahli materi dengan kategori sangat baik, (b) penilaian pengguna/respon siswa dengan kategori sangat baik, (c) aktifitas guru dengan kategori sangat baik, dan (d) aktivitas siswa dengan kategori sangat baik. Dengan demikian produk media pembelajaran telah teruji keefektifannya.

\section{DAFTAR PUSTAKA}

Arsyad, Azhar. 2002. Media pembelajaran. Jakarta: Kriya Pustaka.

Budinigsih, Asri. 2004. Belajar dan Pembelajaran. Yogyakarta: Rineka Cipta.

Candra. 2005. Lingo Director MX 2004. Palembang: Maxicom.

Eggen, P.D \& Kauchak, D.P. 1988. Strategies for Teacher: Teacher Content and Thinking Skils. New Jersey: Prentice Hall.

Hendi Hendratman \& Robby. 2011. The Magic of Macromedia Director. Bandung: Informatika Bandung.

Ibrahim, Muslimin. 2002. Pengembangan Perangkat Pembelajaran. Jakarta: Direktorat Pendidikan Lanjutan Pertama. Depdiknas.

Kemp, J. E. 1994. Proses Perancangan Pengajaran. Terjemahan. Asril Marjohan. Bandung: ITB.

Khabibah. 2006. Pengembangan Model Pembelajaran Matematika Dengan Soal Terbuka Untuk Meniingkatkan Kreativitas Siswa Sekolah Dasar. Disertasi tidak diterbitkan. Surabaya: PPs UNESA.

Mudhofir. 1987. Teknologi Instruksional. Bandung: Remaja Rosdakarya.

Mulyanta, St \& Marlon Leong. 2009. Turorial Membangun Multimedia Interaktif Media Pembelajaran, Kolaborasi Macromedia Director MX, Macromedia Firework, Swish Max. Yogyakarta: Universitas Atma Jaya Yogyakarta.

Rusman, Deni Kurniawan \& Cepi Riyana. 2011. Pembelajaran Berbasis Teknologi Informasi dan Komunikasi. Jakarta: Rajawali Pers

Slavin, Robert. 2008. Psikologi Pendidikan Teori dan Praktek. Jakarta: Indeks

Sugiyono. 2011. Metode Penelitian Kuantitatif, Kualitatif dan R\&D. Bandung: Alfabeta

Thiagarajan, S. Semmel, DS. Semmel, M. 1974. Instructional Development for Training Teachers of Exceptional Children. A Sourse Book. Blomington: Central for Innovation on Teaching the Handicapped. 